\title{
Landscape unbounded: space, place, and orientation in $\neq$ Akhoe Hai//om and beyond
}

\section{Thomas Widlok}

Max Planck Institute for Psycholinguistics, Department of Anthropology, Durham University, Durham, United Kingdom

\begin{abstract}
Even before it became a common place to assume that "the Eskimo have a hundred words for snow" the languages of hunting and gathering people have played an important role in debates about linguistic relativity concerning geographical ontologies. Evidence from languages of huntergatherers has been used in radical relativist challenges to the overall notion of a comparative typology of generic natural forms and landscapes as terms of reference. It has been invoked to emphasize a personalized relationship between humans and the non-human world. It is against this background that this contribution discusses the landscape terminology of $\neq$ Akhoe Hai//om, a Khoisan language spoken by "Bushmen" in Namibia. Landscape vocabulary is ubiquitous in $\neq$ Akhoe Hai//om due to the fact that the landscape plays a critical role in directionals and other forms of "topographical gossip" and due to merges between landscape and group terminology. This system of landscapecum-group terminology is outlined and related to the use of place names in the area.

(C) 2006 Published by Elsevier Ltd.
\end{abstract}

Keywords: Khoisan; Hunter-gatherers; Absolute frame of reference; Orientation; Namibia; Bushmen

\section{Introduction: language and landscape of the "Bushpeople"}

The comparative "Bushman Dictionary", published posthumously in 1956 by Dorothea Bleek, a founding figure in Khoisan studies, provides no entry for 'landscape'. However, by compiling a "Bushman" dictionary Bleek followed the then dominant

E-mail address: Thomas.Widlok@mpi.nl 
European conception that collapsed all languages spoken by "Bushmen" into one lexicon. She also implicitly collapsed the landscape and its people. Like most of her contemporaries she assumed that the way of life of hunter-gatherer groups in the arid regions of southern Africa united the !Xû, Nharo, Hai//om ${ }^{1}$ and others into a single group defined by its association with the landscape they lived in, namely "the bush" (see Bleek, 1956). ${ }^{2}$ Bleek succeeded to show how diversified the languages were that were commonly covered under the label "Bushman languages".

Following this lead, subsequent generations of linguists and anthropologists spent considerable time and effort deconstructing this overarching category into a more systematic typology of Khoisan languages. Khoisanists highlighted the diversity within the spectrum of "Bushman" languages and pointed out that some people classified as "Bushmen" or "San", for instance the Hai//om, speak languages that are more appropriately classified within the spectrum of Khoekhoe languages, i.e. with the other branch of the so-called Khoe-San languages, and more specifically with the Nama ("Khoi", "Hottentot") pastoralists (Winter, 1981; Barnard, 1992). At the same time anthropologists and social historians deconstructed the label "Bushman" itself, arguing that it was an ethnocentric and derogatory term since it suggested a merging of people with the non- or sub-human world of landscape and animals (see Gordon, 1992). As a consequence of this deconstruction, the relationship between the "bush" landscape of southern Africa and the languages of the people living in that landscape became somewhat of a non-topic for the specialists ${ }^{3}$ while it remained a common topic of popular images and stereotypes. For the Hai//om and their language, which are at the focus of this contribution, the issue of ethnonyms has yet another twist. The name Hail/om, by which they are known, is usually translated as 'treesleeper' (hais/haib 'bush/tree'; //om 'to sleep') which re-invokes the associations of "Bushman" (for an example of folk etymology see Schatz, 1993; cf. Widlok, 1999). ${ }^{4}$

\footnotetext{
${ }^{1}$ Following the accepted orthography for Khoekhoekowab languages I use the symbols $\neq, /, / /$, ! for the click (influx) consonants. For more details see Widlok (1999, p. xvii).

${ }^{2}$ For more details on the etymology and the use of the term "Bushman" over time see Barnard (1988) and den Besten (2003). On current naming preferences see: http://www.kalaharipeoples.org

${ }^{3}$ For instance, at a conference entitled Hunter-gatherers in transition: language, identity, and conceptualisation among the Khoisan and funded by a large special research programme of the German Research Foundation, Arid Climate, Adaptation and Cultural Innovation in Africa (Kultur- und Landschaftswandel im ariden Afrika), the relation between language and landscape was only touched upon in a single contribution, despite the overall title of the programme. The resulting publication has excellent contributions covering questions such as orthography, phonology, music, tone and rhetoric and includes specialized questions such as lexical avoidance and the function of privative prefixes but with the one exception does not deal with the landscape at all (Schladt, 1998; see Widlok, 1998). Since then more landscape-centred contributions have appeared in the programme (e.g. Kathage, 2004), although not dealing with Khoisan-speaking hunter-gatherers. Earlier exceptions to this general picture of Khoisan linguistics are Köhler's monumental Die Welt der Kxoe-Buschleute which in its encyclopedic treatment of various domains also devotes a whole volume on place names and related topics (see Köhler, 1989) and the Toponymica Hottentotica (Nienaber and Raper, 1977, 1981), a large but largely non-utilized collection of Nama place names.

${ }^{4}$ Some of my informants in the northern part of the Oshikoto region in Namibia maintain that their autonym is $\neq$ Akhoe whereas Hai//om is a name that was given to them by the Nama (see Widlok, 1999, p. 15) but this view is not shared by the majority of Hai//om living further south. In this contribution, and in the larger language documentation from which it is derived, the label $\neq$ Akhoe Hai//om (see http://www.mpi.nl/DOBES) is used to take account of this fact. I have carried out a total of more than three years of field research with $\neq$ Akhoe Hai //om in the Oshikoto Region in northern Namibia since 1990.
} 
The main objective of this contribution is to re-enter reflections about the relationship between the $\neq$ Akhoe Hai//om language and the landscape in which the $\neq$ Akhoe Hai //om speakers live. The aim is to achieve this in a way that goes beyond the stereotypes contained in the discussion about ethnonyms but also beyond the wide-spread disregard of such "environmental" links that characterizes much of Khoisan linguistics today. As will become clear in the course of my argument I consider the distinction between generic landscape terms and local place or area names to be part of the problem so that we cannot take it for granted. Correspondingly, in this contribution "landscape terminology" covers $\neq$ Akhoe Hai//om vocabulary comprising both local names and generic terms.

\section{Landscape terminology}

The landscape of $\neq$ Akhoe Hai//om country is, indeed, mostly "bush". Today it roughly covers the area in northern Namibia's Oshikoto Region between $17^{\circ}$ and $18^{\circ}$ eastern longitude and between $18^{\circ}$ and $19^{\circ}$ southern latitude. As I will show in more detail below, in this forest savanna and woodland the distribution of dominant bush or tree species changes gradually, most prominently in a south-north direction with higher rainfall and taller trees towards the north (for more details on rainfall and vegetation, see Widlok, 1999). In the central part the thick bush and woodland covers permanent dunes which are generally too low (and the bush being too high) to allow wide vistas. Given the absence of mountains or ridges - except for the most southerly margin of Hai//om country - the only clearly outstanding landscape features shown on general survey maps of the area are dry river beds and water pans. The soil is mostly sandy but with varying degrees of colouring and softness. As I shall show, $\neq$ Akhoe Hai//om landscape vocabulary correspondingly refers to these soil types as well as to the dominant vegetation in an area.

At the face of it, eliciting $\neq$ Akhoe Hai//om landscape-related language is not difficult since it is ubiquitous in discourse. However, there is some difficulty in ascertaining whether the words used in this discourse in fact correspond to generic landscape categories or whether they can be used to distil a system of generic landscape terms. For instance, contrary to what one might expect, elicitation of this vocabulary is possible without the speakers directly engaging with the larger landscape. Two $\neq$ Akhoe Hai//om speakers, seated on a blanket, separated by a screen, their eyes set on the photos and objects of a "space game" in front of them, will talk to one another using language relating to the landscape while seemingly not being concerned with the landscape "out there" but only with the limited space right in front of them. The various sets of space games, developed by the Max Planck Institute in Nijmegen in its "stimulus kit" for research into spatial categories, ${ }^{5}$ that I took to the $\neq$ Akhoe Hai//om field, regularly produced a host of landscape-related language used by the $\neq$ Akhoe Hai//om. When talking about two toy men shown on a photo

\footnotetext{
${ }^{5}$ For a more detailed description of these "space games" see Levinson (2003). I have carried out several different space games in my research using a number of different objects (photos, toy figures, abstract objects) and targetting a variety of cognitive skills (memorizing, inferencing, communicating). In all these tasks the general setup is similar insofar as one or two speakers are asked to solve a task by arranging or identifying the objects (or photos of objects) along a number of different axes and spatial constellations, frequently involving the rotation of the speaker and allowing for a number of equally valid interpretations of a spatial setup.
} 
as part of a photo-matching game $\neq$ Akhoe Hai//om speakers will regularly use descriptions such as the following:

(1)

\begin{tabular}{|c|c|c|c|c|c|c|c|c|c|c|c|}
\hline $\begin{array}{l}\text { Photosa } \\
\text { Photo }\end{array}$ & & $\begin{array}{l}t a \\
\mathrm{I}\end{array}$ & $\begin{array}{l}g e \quad g o \\
\text { PART }\end{array}$ & & $\begin{array}{l}u \text {, } \\
\text { have }\end{array}$ & $\begin{array}{l}\text { I/na } \\
\text { that }\end{array}$ & $\begin{array}{l}\text { photosa } \\
\text { photo }\end{array}$ & & $\begin{array}{l}\text { Igam } \\
\text { two }\end{array}$ & $\begin{array}{l}\text { khoega } \\
\text { men }\end{array}$ & $\begin{array}{l}\text { uuhã, } \\
\text { have }\end{array}$ \\
\hline $\begin{array}{l}o b \\
\text { and }\end{array}$ & $\begin{array}{l}g e \\
\text { PART }\end{array}$ & $\begin{array}{l}\text { Iguiba } \\
\text { one }\end{array}$ & $\begin{array}{l}\text { //go- } \\
\text { plant sp. }\end{array}$ & & $\begin{array}{l}\text { aiba } \\
\text { place }\end{array}$ & $\begin{array}{l}\text { loa } \\
\text { toward }\end{array}$ & $\begin{array}{l}\text { loa } \\
\text { turn }\end{array}$ & $\begin{array}{l}h \tilde{a}, \\
\text { is }\end{array}$ & $\begin{array}{l}o b \\
\text { and }\end{array}$ & $\begin{array}{l}g e \\
\text { PART }\end{array}$ & $\begin{array}{l}\text { Iguiba } \\
\text { one }\end{array}$ \\
\hline $\begin{array}{l}\text { !aeba } \\
\text { river area }\end{array}$ & & $\begin{array}{l}\text { loa } \\
\text { toward }\end{array}$ & $\begin{array}{l}\text { loa } \\
\text { turn }\end{array}$ & $\begin{array}{l}h \tilde{a}, \\
\text { is }\end{array}$ & $\begin{array}{l}o b \\
\text { and }\end{array}$ & $\begin{array}{l}\text { ge } \\
\text { PART }\end{array}$ & $\begin{array}{l}\text { soaba } \\
\text { space }\end{array}$ & $\begin{array}{l}\text { !nãga } \\
\text { between }\end{array}$ & $\begin{array}{l}m \tilde{a}, \\
\text { stand }\end{array}$ & $\begin{array}{l}o b \\
\text { and }\end{array}$ & $\begin{array}{l}\text { hoa } \\
\text { all }\end{array}$ \\
\hline $\begin{array}{l}\text { hoega } \\
\text { hen }\end{array}$ & & $\begin{array}{l}\text { !huni } \\
\text { yellow }\end{array}$ & $\begin{array}{l}\text { hairoga } \\
\text { sticks }\end{array}$ & & $\begin{array}{l}\text { uuhã. } \\
\text { have }\end{array}$ & & & & & & \\
\hline
\end{tabular}

'I have a photo, that photo has two men, and one of them is turned to the north [area of the //go fruit], and one of them is turned to the south [area of the river], and there is a space between them, and all men have yellow sticks.'

When transcribing and glossing these texts I routinely used the cardinal terms north/ south/east/west for the landscape names being used. As I have shown elsewhere (Widlok, 1997) $\neq$ Akhoe Hai//om do have excellent orientation skills and they use landscape names to point to the cardinal directions. Or, to put it the other way round, the use of this vocabulary in a continuous flow of "topographical gossip" (Widlok, 1996) is probably a major factor in developing and maintaining the skill to be able to orient oneself and to point accurately to distant places in these tasks. However, this landscape vocabulary is not a system of cardinals in the strict sense. The description cited above (1) only applies when the speakers are placed in the /Gomaib ('Mangetti-area') area from where the landscape to the north is called //Goaib ('area of the //go tree') and that to the south is the river area (!Aaib). Once you move to the river area, /Gomaib is north, and south is now /Khomab ('Mountain-area'). When placed south of the river area, the !Aaib ('River-area') is north and so forth. Fig. 1 (adapted from Widlok, 1999) summarizes the landscape terms in a north-south transect of the region where $\neq$ Akhoe Hai//om is spoken. As one might expect $\neq$ Akhoe Hai//om speakers from /Gomaib find it difficult to name what they would call 'south' if they are presented with the hypothetical question as to what the south would be called once they reach the most southerly landscape of their region, namely the mountains of the highland (/Khomab). Some speakers will then shift to use a place name as a cardinal instead. For 'south' they would routinely refer to Windhoek, Namibia's capital, which is known to be down south, and for 'north' they would refer to regional towns such as Okongo, near the Angolan border, which they or their family members have visited in the past. The landscape vocabulary is therefore not exactly a system of cardinals since it is relative to one's position although it is not relative in the sense that it does not change in reference to the communicative space between interlocutors as 'left' and 'right' do. Moreover, a replacement with ad hoc landmarks is possible. Examples are a car parked or a house that is situated in, say, the northerly direction of the speaker, or place names as in the following instance: 
(2)

Khoeba $i$ bi !narese loa loa n1 mã, soxa lgom- aisa !oa. Man is he Owamboland towards turn PART stand taboo Tree sp. place toward

'The man stands towards the !nares [land of the Owambo, north], towards the place of the taboo Mangetti tree [a cattle post].'

Moreover, distinctions made within the landscape vocabulary do not systematically follow a single feature such as landform or habitat type. Apart from what are typical landscape features according to geomorphologists or surveyors, namely mountains and rivers, other features also play a role, above all soil types with the characteristic consequences for mobility and water availability and vegetation with its relevance for foraging. The landscapes //Goaib and /Gomaib are both named after important wild foods, while the Tsabob and Gogarab are named after the prevalent soft and hard ground (see Fig. 1). The features are of course connected to one another in that the //go and the /gom trees only grow on certain soils and in that the soft and hard ground each are home to a distinct set of vegetation. Furthermore, the $\neq$ Akhoe Hai//om vocabulary is, strictly speaking, a land-cumpeople terminology. People not only come in as those who select salient features (the //go and /gom are not the most numerous plants in these landscapes but they have cultural salience as resources), landscapes and people are also regularly fused with one another. In $\neq$ Akhoe Hai//om the landscapes mentioned are frequently used in reference to the people living there, for instance tsabo!hukhoen refers to 'the people of the hard ground' and /khomakhoen to 'the mountain people'. Given that places in the landscape are inhabited by people, at least at times, the topographical gossip also routinely links the landscape via the people living there with the places that they inhabit.

I have argued that this multifocality is an important feature of the $\neq$ Akhoe Hai//om way of talking about space and place as well as for moving within their lived space (Widlok, 1997). Orientation in both discourse and physical space is facilitated by the fact that

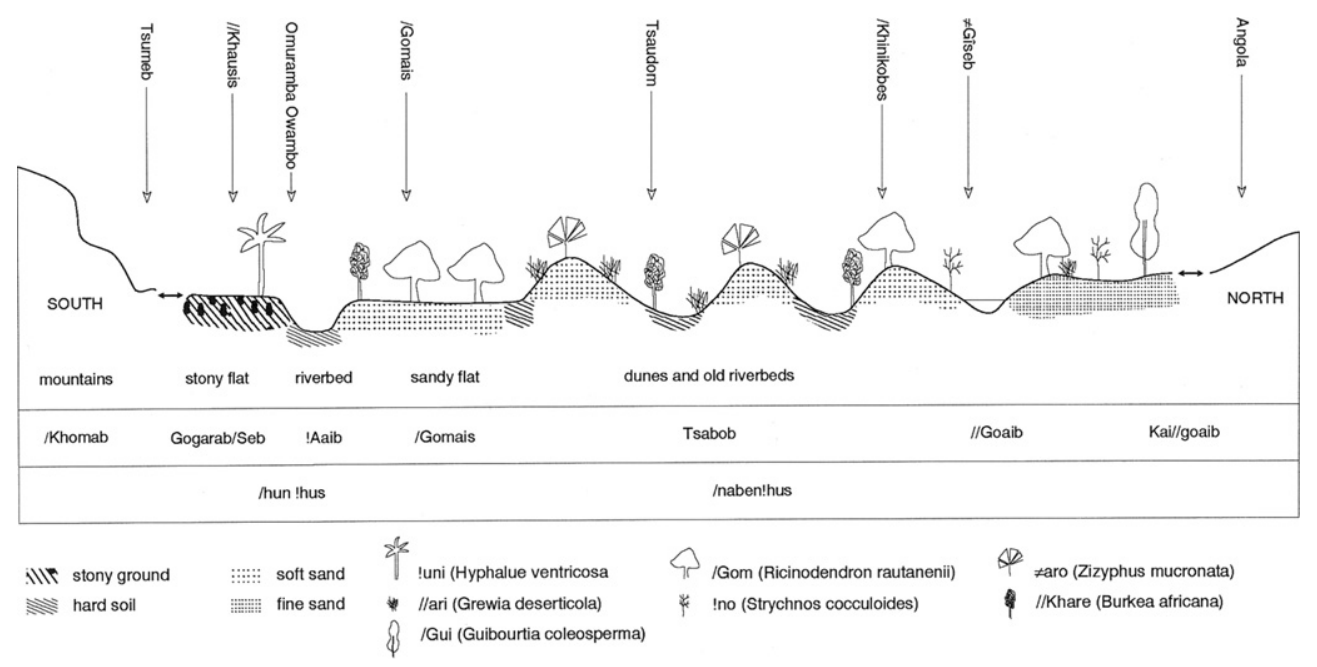

Fig. 1. North-south transect through $\neq$ Akhoe Hai//om country (altitudes vertically exaggerated, distance covered approx. $75 \mathrm{~km})$. 
when talking about people and places, the landscape and its salient features are also talked about. Talking about the 'land of the soft ground' not only evokes images of certain people living there, and of certain food plants growing there, but also of a certain way of movement, namely heavy walking through soft sand. The river land, to take another example, similarly evokes images (memories and expectations) of a linear oasis, a dry river bed (the "rivers" in this area hardly ever flow), open spaces with grass and muddy water pools frequented by animals coming to drink at these pools. It also invokes "historical" aspects such as the fact that the river bed was used as a road for ox-wagons by the early colonialists, the traders and commercial hunters, and that the land surrounding the river was given to white settlers. Not surprisingly, therefore, a common synonym for the river land and the landscapes further south is 'land of the white men' (!urikhoen!hus) while the land to the north is also known as !nares or Inaben!hus ('land of the Owambo', the Bantuspeaking neighbours of the $\neq$ Akhoe Hai//om).

The landscape vocabulary outlined above does not form a neat and complete set as one might expect given its importance in orientation and conversation. It is flexible in that speakers can scale in or out using either words for large landscapes or for smaller landmarks, referring to "lasting" features such as the ground or to ad hoc features such as cars being parked at a place. Moreover, the rich use of landscape vocabulary for the northsouth axis is not matched by a parallel system for east-west. On this axis two "true" cardinal terms are most often used, as in the following example that was recorded in conjunction with phrase (1):

(3)

\begin{tabular}{|c|c|c|c|c|c|c|c|c|}
\hline $\begin{array}{l}\text { Photosa } \\
\text { Photo }\end{array}$ & $\begin{array}{l}\text { ta } \\
\mathrm{I}\end{array}$ & $\begin{array}{l}\text { ge go } \\
\text { PART }\end{array}$ & $\begin{array}{l}u u \text {, } \\
\text { have }\end{array}$ & $\begin{array}{l}\text { Igam } \\
\text { two }\end{array}$ & $\begin{array}{l}\text { khoega } \\
\text { men }\end{array}$ & $\begin{array}{ll}\text { uuhã, } & o b \\
\text { have } & \text { and }\end{array}$ & $\begin{array}{l}g e \\
\text { PART }\end{array}$ & $\begin{array}{l}\text { lguiba } \\
\text { one }\end{array}$ \\
\hline $\begin{array}{l}\text { sore } \neq \text { gãsa } \\
\text { sunset }\end{array}$ & $\begin{array}{l}\text { loa } \\
\text { towards }\end{array}$ & & $\begin{array}{l}\text { garu, } \\
\text { walk }\end{array}$ & $\begin{array}{l}\text { lguiba } \\
\text { one }\end{array}$ & $\begin{array}{l}\text { Igamba } \\
\text { warmth }\end{array}$ & & $\begin{array}{l}\text { loa } \\
\text { towards }\end{array}$ & $\begin{array}{l}\text { garu. } \\
\text { walks }\end{array}$ \\
\hline
\end{tabular}

'I have a photo, it has two men, and one of them walks towards the west [where the sun goes in], one of them walks to the east [the warmth].'

Here, the rise and the setting of the sun become the reference points, overshadowing all other possible directionals at least in terms of the frequency in usage. But again flexibility is possible. Not only is sore $\neq$ oas ('the sun comes out') frequently replaced for Igamb ('warmth') but other replacements also occur. The replacements include landscape references such as Xom!hus (referring to the Etosha pan in the west) or places and ad hoc landmarks as outlined above. This "asymmetry" in the axes, to be discussed below, deserves more attention because it seems to reach "deep" into non-linguistic cognition as well as into the domain of social practice and because it does occur in other languages, as well.

A comparison of directional terminologies of the languages in the region shows that other Khoekhoe (Khoisan) speakers like the Nama differ from Hai//om in that they use "fixed proper terms" for the north-south axis and the names of prevalent winds on the east-west axis (see Neumann and Widlok, 1996). By contrast, some of the Bantu-speaking groups in the region use the sun as a reference point for the east-west axis and contingent names for neighbouring peoples on the north-south axis, i.e. showing structural similarities with the $\neq$ Akhoe Hai//om system, while others have "proper" (unchanging) terms for 
east-west (sun) as well as north-south (winds) (Neumann and Widlok, 1996). However, there is evidence to suggest that these similarities and differences in directional vocabulary (and its etymology) are in fact secondary to the effect that the various pragmatic uses of these vocabulary sets have. To begin with, the instances of $\neq$ Akhoe Hai//om use of landscape-related language clearly outnumber that of a group of Bantu-speakers living under very similar environmental conditions who tend to use terms such as left and right (Neumann and Widlok, 1996, p. 354).

In other words, and in a partial rephrasal of my opening statement, it is not so much that landscape terminology emerges in $\neq$ Akhoe Hai//om discourse taking place in the small space in front of speakers as "extensions" from the landscape that may seem to be detached "out there" to the observer. Rather, the landscape and landscape vocabulary saturate all spatial relations (and spatial talk) thereby dissolving, or at least diluting, the boundary that geographers may draw to separate the landscape from the spatial features on a smaller scale in front of you and indeed from the non-spatial domain. This view is supported by ethnographic evidence (see Widlok, 1999, forthcoming) on the uses of space, in terms of architecture, bodily movements and the use of resources. In $\neq$ Akhoe Hai//om practice the "natural" landscape merges with built environment, with settlements and bodily space (see Widlok, forthcoming). An apt illustration of this point is a row of bushes, which can be both a feature of the environment and a feature of settlement, since it is used as a wind shield for the purpose of shelter and for storing things (see Fig. 2). Moreover, for $\mathrm{a} \neq \mathrm{Akhoe} \mathrm{Hai} / /$ om speaker the landscape vocabulary is in a variety of ways connected to names of specific places so that generic landscape terms and place naming are not rigidly separated. To begin with, the landscape names given above (and summarized in Fig. 1) are referring to specific areas and is not generalizable across all contexts. The words being used may be more appropriately called landscapes names rather than technical landscape terms. There are Mangetti trees elsewhere (and more place names that refer to them) but there is only one area called /Gomaib ('the Mangetti'), given that it is the largest of all Mangetti groves. There are also other (dry) river beds (and they may be referred to as !ab or dom) but there is only one !Aaib ('the River-area'), the Omuramba Owambo being the largest of all river beds in the region.

Are we then to conclude that there are no generic landscape terms in $\neq$ Akhoe Hai//om and that they only have landscape names? At least we seem to be better advised not to

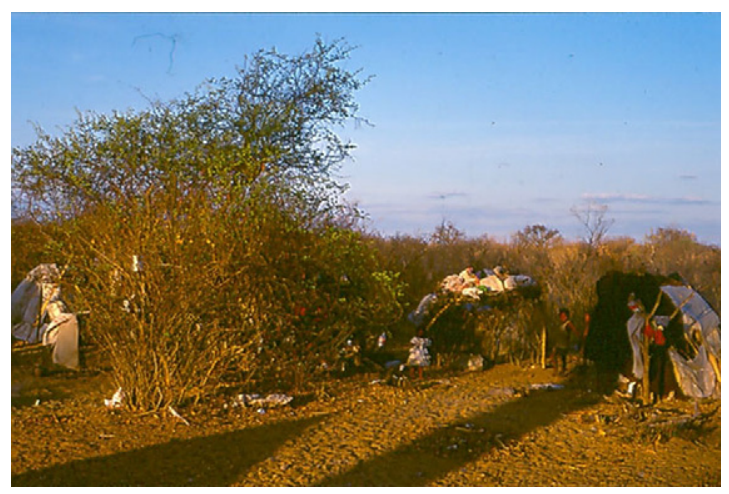

Fig. 2. Wind shield and bushes as dwellings. 
restrict their terminology prematurely according to our classification. $\neq$ Akhoe Hai//om has words like ! $a b$ which can be turned into a generic term (as is clear when speakers are shown photos of rivers or river beds they do not know). However, it is also turned into a name, namely the name of the largest and most prominent river bed in the area. I think it is futile to try to establish whether ! $a b$ was "originally" a generic landscape term that later became a name of a specific river which later was generalized into a directional term. Or that !nares was initially a place name (for the residence of the Ndonga Owambo king) and then became a generalized term for north. Rather, these words are exemplary cases of the more general observation made in language philosophy (Løgstrup, 1991, p. 64) and more recently again in language pragmatics (Hanks, 1996, p. 141) that words are not regionally bound but indeterminate. They can be expanded "laterally" across cases including what we as speakers of artificial scientific languages generally see as a "vertical" movement between generic terms and specific names. In the case discussed here one could even argue that ! $a b$ is already a compound since ! $a$ may be developed into ! as (place) or ! ab (river) with the help of gender markers (see below). The separation of regions and of generics from names which is central for descriptions in the natural sciences is in fact a very special case since it is in many ways counterproductive in everyday cognition and language (see Løgstrup, 1991, p. 122). In the case under consideration here the landscape vocabulary - although referring to larger areas - also shares critical features with place names and, as is described in more detail below, there are frequent shifts between place names and the landscape vocabulary.

There is, thus, a discrepancy between the use of language by $\neq$ Akhoe Hai//om speakers and the overall framework on which much comparative research (including the contributions to this collection) is being based, namely that which presupposes a separation between a culturally informed system of (place or landscape) names from a system of generic terms for landscape features. In other words the challenge that arises from the $\neq \mathrm{Akhoe} \mathrm{Hai} / /$ om evidence is not that, say, they would have more words for 'bush' than Indo-European languages but rather that they draw no boundary between generic landscape terms and culturally specific names. To insist that there has to be rigid distinction between the historically situated names for places or landscapes and generic terms for landscapes or their features may be indispensable for certain ways of doing comparative research but, it seems, not for relating to the landscape as hunter-gatherers like the $\neq$ Akhoe Hai//om do.

\section{Place names in the landscape}

Apart from the frequent pragmatic replacements and shifts between landscape and place names, there are also elements in $\neq$ Akhoe Hai//om grammar that facilitate a smooth connection between the landscape vocabulary described above and place names. All Khoekhoe languages use the gender markings $-s$ (for feminine) and $-b$ (for masculine) unless the unspecific neuter gender marking $-i$ is being used. The general rule of thumb is that, for material objects, small and roundish things, for instance a bush (hais), receive the feminine gender marker whereas long and tall things, for instance a high tree (haib), receive the masculine marker. In standardized Khoekhoe this rule is applied to distinguish, for instance, !hub ('land, landscape') from !hus ('piece of land or property') (see Haacke and Eiseb, 2002, p. 339) and !ab ('river', or 'locality + longish') from ! as ('settlement', or 'locality + roundish'). However, there is a danger of committing "the fallacy of the 
rule" here since the application of gender markers are frequently subject to pragmatic considerations as situational and individual motivations inform the language and its use. Speakers may use the feminine gender marker to downplay, as in maris ('only a little money') or to exaggerate as in marib ('riches, a big amount of money') for there is no "objective" threshold where small money (maris) becomes big money (marib). Similarly, the words used for landscapes may routinely receive a masculine marker but when talked about in terms of the land as belonging to a certain group of people may also receive a feminine marker. Each landscape mentioned above is a !hub ('land'), the same term used to refer to the territory of a nation state or country, but it may also be referred to as di!hus ('my land'). Place names may have a masculine or a feminine gender marking. The list of place names given in Table 1 contains predominantly feminine gender markings but this is partly due to the common place name ending -ais which is the feminine form of the ending - aib that occurred in the list of landscape names given above. $A i$ without a proper name usually carries the meaning 'surface', and even more commonly 'face'. In its combination with a proper place name, as in /Gomais ('place of the Mangetti trees') it does not necessarily mean that this place is of a different size or shape as another place with a masculine gender marker (e.g. Daniseb) but it can be used to create a contrast with /Gomaib 'area of the Mangetti trees' which also occurs and refers to the larger area comprising many cattle posts. I did not find a case of places or landscapes with a neuter gender marker. However, in compound nouns, as in //Goaikhoen ('people of the //go [fruit sp.] area') the gender classifier for $a i$ is dropped and a neuter marker may also be applied to the compound as a whole (khoe-i 'person', khoe-n 'people'). ${ }^{6}$

The point of this discussion is not to determine the origins or structural features of the Khoekhoe gender suffixes but to show that the language, as it is presently spoken, provides an easy means for speakers to gloss over from the use of landscape names to the use of place names and vice versa. Moreover, places and landscapes share structural features: both have fuzzy boundaries and both are a conglomerate of what geographers tend to separate into cultural and natural elements. Looking at place names more closely it is possible to distinguish forms that are "regular" in the sense that they occur frequently and are most easily glossed. Those are for instance Tsau-dom (proper name + dom [another term for dry river bed]) or /Nore-ais ('place of the Inore [a sp. of wild fruit]'). Instead of $\neq$ khia-ais ('place of the $\neq$ khia fruit') the shorter $\neq$ khias may also be used so that the ending -ais becomes an optional suffix that can but need not be added to place names. A good example for the "merging" (or rather: for the keeping together) of cultural and natural features is the name Soxalgom-ais ('place of the taboo Mangetti tree'). $\neq$ Akhoe Hai//om are generally not concerned about etymologies in the way that many Europeans living in this area tend to be (see for example Berry et al., 1996) which means that for some place names a "meaning" is offered without hesitation while in many cases there is none, or at least no concern shown about etymological meanings. ${ }^{7}$

\footnotetext{
${ }^{6}$ It has been suggested (Haacke, 1977) that the gender endings are strictly speaking separate lexemes.

${ }^{7}$ In the particular case of the 'place of the forbidden Mangetti tree' I kept pressing one of my informants so hard to tell me more about that taboo Mangetti tree that somewhat unnerved he asked back whether I had not read the Bible where they also talk of a tree from which one should not eat. This leads to the interesting, but intricate, question for the reasons of "forgetting" (or not being willing to discuss) the etymological meaning of place names. I do not think that in this particular case a possible unwillingness to discuss the etymology was an issue but that this was simply not considered to be relevant.
} 
Table 1

$\neq$ Akhoe Hai//om names of cattle posts in the Mangetti area.

\begin{tabular}{lll}
\hline Number of cattlepost & $\neq$ Akhoe Hai//om name given & Comments given \\
\hline 1 & Sabakus & \\
2 & Soxa/gom-ais & Lit. 'forbidden Mangetti tree' \\
3 & $/$ Nore-ais & Named after a wild fruit \\
4 & $/$ Gõandis & Lit. 'place of children' \\
5 & $/ /$ Obetatõas & \\
6 & $/$ Nãi $\neq$ gab & Alternatives: /Nĩ $=$ gab, !Gotsamab \\
7 & Tã/uis & Lit. 'different stone' \\
8 & $/$ Khai-ais & Lit. 'nothing place' \\
9 & $\neq$ Khias & Named after a wild fruit $(\neq \mathrm{khia})$ \\
10 & Khanusas & Lit. 'enough water to satisfy thirst' \\
11 & Khauas & \\
12 & $/$ Garus & Lit. 'mad people' \\
13 & Khuios & \\
14 & Daniseb & Lit. 'place of bees [dani-e]' \\
15 & $!$ Khangudis & Lit. 'place of eland antelope [!khanda]' \\
16 & $!$ Ao $\neq$ gareb & Lit. 'many leaves of trees'
\end{tabular}

A similar apparent disinterest in etymology and the orthodoxy and constancy of names emerges with regard to places that $\neq$ Akhoe Hai//om share with members of other language groups. One of the places in an area that only twenty years earlier had been converted from unfenced $\neq$ Akhoe Hai//om land into fenced farms for rich Owambo agropastoralists is now called Daidams by the current Owambo farm owner. He maintains that this is the original name given to the place by the local "Bushpeople" and it is important to him that he has kept this name, thereby expressing his legitimate taking over of the land from the first occupants - a common feature in the expansive internal African frontier of Bantu-speaking agropastoralists (Widlok, 2003; see also Williams, 1991; Kopytoff, 1989). In terms of the linguistic form of the name, its Khoekhoe origins are indeed likely, even though a number of etymologies or derivations are possible since a loss of clicks through transferral into a non-Khoisan language is likely to have occurred. Today, there are also $\neq$ Akhoe Hai//om staying at Daidams, now as farm hands of the Owambo. However, they call the place //As ('satisfied hunger' would be a possible etymology) and maintain that this is the only name the $\neq$ Akhoe Hai//om have given to the place. This case seems to reflect different concerns about land and place, in particular with regard to the objectification of land as a property item (a place named is a place owned) - which hunter-gatherers, unlike many of their agropastoralist neighbours, only reluctantly accept (see Ingold, 2005).

Europeans in Namibia and elsewhere insist that you need to have a name for a place in order to claim ownership (and that naming is an element of claiming ownership), just as they insist that you need to have a set of generic landscape terms in order to categorize and be familiar with the land you live on. It seems that this view is not universally shared as the merging of places and the landscape in $\neq$ Akhoe Hai//om practice substantiates. It does not take Hai//om speakers much to "make" a place, materially or toponymically. When I collected lists of place names asking informants to describe their route from our ordinary place of residence (and the place of speaking) to a distant place in the //Goaib, which required several days of walking, every person came up with a slightly different list. The 
lists reflected the places at which each group had stopped and rested or stayed overnight. The lists were not only individual selections of a larger "complete" list of places but some places en route became places by the act of resting there. When stopping mid-way on a journey asking informants for the name of the place, they would "stretch" the name of the settlement or site that we were approaching or had left, typically a place with a water source. I did not investigate systematically how far the names of places or sites could be stretched in that way. It seemed that it was always assumed that all "places" had a name, very much like beads on a string, either because they were contained in a named landscape (so that this name could be used as a last resort) but also because a place became a place as soon as one stopped and rested. At the same time any single person could not be expected to know all of them. Similarly, the list given as Table 1 was elicited using the European grid of boreholes drilled in the Mangetti area where the parastatal cattle raising development organization had "named" the cattle posts by numbering them. All boreholes had also received $\neq$ Akhoe $\mathrm{Hai} / /$ om names that were widely shared and agreed upon, including the name /khai-ais (Number 8) which can be glossed as 'nothing-place', i.e. a place where possibly there was nothing worthwhile to single out the place from the named landscape before the borehole was drilled and the cattle post was established. Apart from naming these "new" places, each of these cattle posts created and identified by Europeans has a number of surrounding "old" places, not recognized by the Europeans but by the $\neq$ Akhoe Hai//om who remember earlier occupancies and camp sites. As with other foraging groups the $\neq$ Akhoe Hai//om regularly revisited areas, water holes and places of rich wild food, but always camped a little distance away from their previous camp sites (see Barnard and Widlok, 1996). Toponymically, these different sites may be taken together, especially when ultimately referring to a single water source, or they may be separated. A larger place such as /Gomais may also be split into smaller units like laba!anis ('red mound'), $\neq$ nu!hoas ('black depression') and !uri!hums ('white hill') which may be considered to be similar to the landscape names described above, only on a smaller scale (Widlok, 1999, p. 85). They are, again, more akin to names rather than generalizable terms. They are most likely derived from terms that are not restricted to the land ('anis 'side', !hoas 'curve', !hums, derivation uncertain) and by adding the colour terms they effectively are turned into names. Given the possibility of merging places with the landscape and of merging places with one another as they shade into one another, speakers have considerable freedom in their naming practices and, as with other aspects of San culture, there is little concern for orthodoxy.

\section{Orientation through the categorical system}

Many $\neq$ Akhoe Hai//om people have outstanding skills of orienting themselves. This skill emerges in the everyday practice of moving through the bush as well as in rather artificial pointing tasks set up by the investigator (see Widlok, 1997). $\neq$ Akhoe Hai//om subjects were able to point correctly in the direction of places that were out of sight and at considerable distance. In this task they surpassed European subjects by far. Given this expertise we might expect that the Hai//om have brought to perfection and to particular sophistication one of the systems of linguistic reference (and spatial cognition) that have been identified cross-linguistically (see Levinson, 1996, 2003). Two of these systems, or "frames of reference", (the "absolute" and the "relative" frames) lend themselves particularly to orientation, the third (the "intrinsic" frame) being inherently orientation-free. 
The two orientation-bound systems have been variously labelled but are based on a distinction between egocentric (relative) and geocentric (absolute) orientation, i.e. relying either on the human body or the landscape as frames.

Levinson, reviewing the extensive literature on human and animal orientation skills, points out that "relative coordinate systems may favour 'piloting', navigation by constant reference to familiar landmarks, while absolute coordinate systems favour true 'deadreckoning' types of navigation" (1996, p. 23). Both systems can be distinguished by the "merits" they have when solving real-life tasks. The absolute system, which has been likened to a compass, avoids specific viewpoints and therefore is logically superior when it comes to transitivity and fixing things spatially when the observer is mobile (e.g. turning or rotating). The relative system, by contrast, can rely on egocentric visual memory without the need to constantly maintain fixed bearings such as east/west and north/south. Some animals gain high proficiency in these systems, but unlike humans they do not learn to switch between different systems nor are they able to combine them (cf. Levinson, 1996, p. 23).

Contrary to what the notion of integrated geocentric/absolute versus egocentric/relative systems may suggest, the Hai//om language neither possesses a perfect geocentric system of cardinal terms in this narrow sense nor a perfect egocentric system of spatial terms to guide speakers through space. As pointed out above, the Hai//om absolute reference system is unlike systems used by some groups of Australian Aborigines, for instance, in that it differs in many ways from a compass. Linguistically, the absolute frame of reference of the $\mathrm{Hai} / / \mathrm{om}$ is based on the course of the sun and on a contingent landscape vocabulary but for both axes alternative ways of expressing direction and location, namely in relation to the body, do exist. The landscape terminology used may be said to be vague and variable, since it does not always form a complete set (see Widlok, 1997, 2007). By the same token the Hai//om relative terms are not readily extended into other domains and remain undeveloped in comparison to strong relative systems like those employed in route descriptions (or in object manipulations) of speakers of English or other Indo-European languages. Frequently, the "relative" terms such as left/right (//are/khab and am/khab, lit. 'left-body' and 'right-body') are in fact used intrinsically, i.e. they take the sides of the object under consideration as their point of reference (see Levinson, 2003). Hai//om seem not to routinely translate the information contained in mental maps into body-centred information in the form of indexical expressions such as 'Turn left, here!'. Are these indications that Hai//om "mix" and combine what appears to the cognitive scientist to be not only two linguistically but also logically (and presumably neuro-physiologically) distinct systems? The results of spatial inference tasks in which the two axes of the body-centred and the landscape-centred frames were tested against one another suggest the following picture $^{8}$ :

\footnotetext{
${ }^{8}$ The tasks demand a non-linguistic response to a problem of identifying objects in spatial relations with one another, prompting either the left/right and front/back axes of one's body or of objects or the east/west and north/south axes of the cardinal system grounded in the landscape (see Levinson, 2003; Widlok, 2007; Haun et al., forthcoming). The results for $\neq$ Akhoe Hai//om show that the strong "absolute" tendency found in discourse is also present in the inference task. Moreover, a similar asymmetry with regard to the axes occurs. For details on the task see Widlok (2007).
} 


\section{RUN 1}

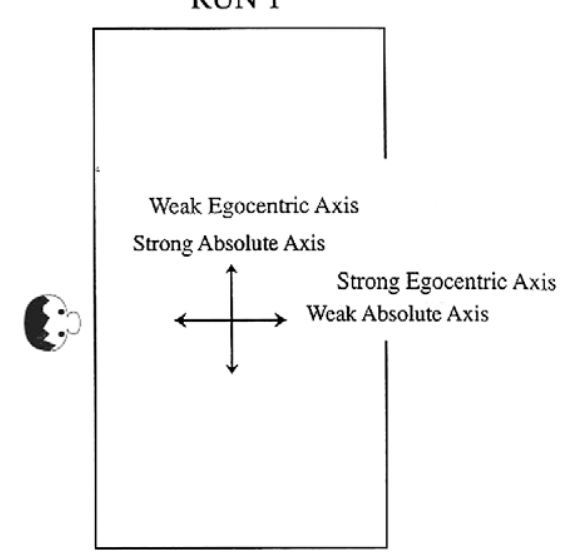

RUN 2

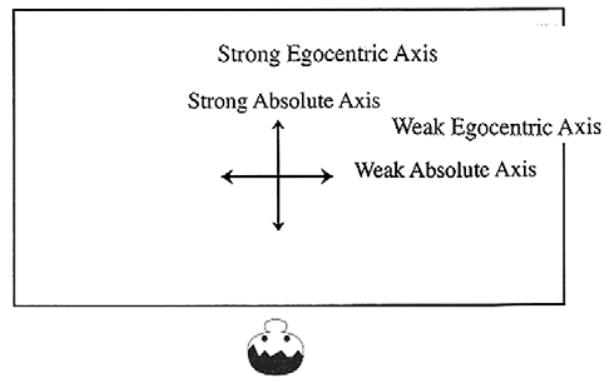

Fig. 3. Spatial tasks involving a systematic combination of absolute and egocentric axes.

- On the whole the landscape-centred frame at work is stronger than the body-/objectcentred frame. That is to say, when responding to the tasks, Hai//om informants tend to rely on an absolute frame of reference rather than a relative or intrinsic one.

- Within this absolute system, the east/west axis is stronger than the north/south axis.

- Within the overall weak non-absolute system the front/back axis is stronger than the left/right axis.

- The two frames of reference or systems interact in a specific way, namely the relatively strong front/back axis comes in when it coincides with the relatively weak north/south axis but not so much when it coincides with the strong east/west axis (see Fig. 3).

In other words, $\neq$ Akhoe Hai//om can conceive and express both egocentric (relative) ${ }^{9}$ and geocentric (absolute) directions and relations. $\neq$ Akhoe Hai//om common sense may construe the coordinate systems differently from the way that the dominant European

\footnotetext{
${ }^{9}$ The question as to whether the non-absolute expressions in the Hai//om language should be considered to be relative or intrinsic (see Levinson, 2003, pp. 34-38) need not concern us here since it is the contrast to an absolute frame which is important. The original task did not distinguish relative from intrinsic responses but in a recent rerun of similar tasks that distinguish all three frames of reference Haun et al. (forthcoming) verified the overall reliance on absolute frames among $\neq$ Akhoe Hai//om speakers with very few intrinsic responses $(15 \%$ versus $85 \%$ absolute) and with relative responses only occurring when being prompted by the investigator.
} 
philosophical tradition does. Instead of superordinating the distinction between subject (relative/ego) and environment (absolute/geo) it conventionalizes an association between east/west and front/back, above all in the domain of walking, disregarding other possible associations. There are a number of ethnographic findings that substantiate this point.

Hai//om spatial activity combines piloting (usually wayfinding along known paths and landmarks) and dead-reckoning (usually navigating on a new route). Although most Hai //om today live in permanent settlements they are nevertheless a highly mobile group. Extended visiting, and moving between permanent settlements, or between permanent, semi-permanent and non-permanent camps, is for the most part still done on foot and in small groups. The landscape is partly woodland, partly open bush land so that it recommends itself to walking on established paths. The paths in the bush are in most cases not well-trodden and usually rather narrow. They only allow walking in line which is in any case the preferred way of travelling. Often, though not always, the more senior people walk in front, especially if they know the route and if they know the clues they are looking for such as animal or human tracks. The people who walk behind may follow at some distance as they often gather fruits on the way or simply because their walking speed is different. If the person walking in front is out of sight, those behind also need to "pilot" their way as they follow the fresh tracks of the person walking in front. Extending the experience of walking in line into other fields is a well-established practice in Hai//om. People frequently refer to younger people as "following" older ones in an ongoing process of life and relative age is made explicit by presenting the younger person to "walk in front" of the other person who "is following behind". Furthermore on an even larger scale social and ethnic groups are considered to follow each other, with disadvantaged people like the "Bushmen" being "left behind". The terms aise ('in front') and khause ('behind') themselves are clearly linked to the body parts ais ('the face') and khaub ('the behind'). Hai //om do not extend the notions of left and right in a similar way, and not to the same extent that for example Indo-European languages do. ${ }^{10}$ Thus, with regard to relative terms it is only the front (aise) and back (khause) axis and its extensions that features strongly in everyday practice and conversation that help to familiarize children with the concepts and to entrench them across situations.

Apart from piloting their way on established paths between places, Hai//om frequently rely on their dead-reckoning skills, that is finding a new way (e.g. a short cut) without retracing one's steps. They rely on good orientation skills as they frequently travel in the bush away from roads and paths searching for food. In the process they are being guided by the distribution of resources in space - to which they often refer indexically for instance at the sight of the nearest fruit-bearing tree - rather than by a fixed route. Their exceptional skills to eventually return to their point of departure also takes advantage of the set of landscape categories, described above, that contain a host of crossdomain information in combination with a good indication about the distance covered, i.e. the speed of travelling. Keeping a good record of both these sources of information in social interaction provides the necessary constraints required for successful orientation (Widlok, 1997; see Hutchins, 1995, pp. 56-57).

\footnotetext{
${ }^{10}$ Examples are expressions in path descriptions such as 'turn left' but also the culturally loaded uses of left and right (such as in 'he acted as her right hand') that are wide-spread across the globe (see Hertz, 1960; Needham, 1973). In Hai//om only 'straight' is morally loaded.
} 
The landscape categories refer to the natural and social environment particularly as it changes from south to north following the climate and vegetation zones. The north-south distinction is phrased in terms of adjoining landscapes, from the arid, stony and bushy country dominated by the livestock enterprises of commercial farmers (and their Hai //om labourers) in the south to the sandy woodlands with limited agriculture and limited autonomy of black communities (and the Hai//om minority living among them) in the north. The river beds and the permanent dunes extend in east-west direction creating an undulating north-south transect (see Fig. 1). Far less changes occur from east to west. This axis is also important for orientation purposes but it is not always nor necessarily implied in the north-south distinction as the two axes are independent to some degree. The east-west axis is used in some contexts in which north and south are irrelevant (when measuring time, when positioning huts and fire-places). Correspondingly the north-south axis (when comparing landscapes, their people and resources) does not necessarily involve the east-west axis. Given the fact that several categories may be used to designate north and south (the nearest landscape or one that is further away, a geographically small or a bigger landscape, a place that stands for a landscape etc.), there are, at least in terms of conversation, several possible north-south axes that can be matched with the one cardinal east-west axis. Keeping these distinctions in mind it is not surprising, therefore, that Hai//om conventional wisdom should see the combination of front/back with east/west as common sense and as "natural" as Europeans tend to consider coordinating front/back with left/right, and east/west with north/south. By contrast, it is not common sensical for Hai//om when orienting themselves in their environment to coordinate left/right with east/west or left/right with north/south. There is no field of activities and no domain of language use in which these combinations are established or entrenched. Thus, what appear to be "mixed" results reflect the goal-oriented strategies adopted in common tasks, above all the common tasks of orienting oneself in space, or more precisely of piloting and dead-reckoning.

\section{Conclusion: environment and origin}

In debates about linguistic relativity it has been a working hypothesis that environments (and the ways of life adapted to them) are likely to be reflected in language and thought, especially in the case of hunter-gatherers whose way of life seems to depend so directly on environmental conditions. It seemed to be reasonable to expect that "the Eskimo" have a hundred or more words for snow - or at least numerous ways of expressing a large variety of snowy conditions. $\neq$ Akhoe Hai//om does not have a hundred words for bush, although they may have more than a hundred names for places "in the bush". Like other hunter-gatherer groups in the region they also do not have a more extensive encyclopaedic knowledge about plants, soil types or other features of the environment than their agropastoralist neighbours. At least in part the evidence collected has been counter-intuitive. In ethnobotany, for instance, it is not the case that hunter-gatherers "naturally" or necessarily have a richer taxonomy than their neighbours. To the contrary, at least in some cases, the division of labour and the hierarchical system of agriculturalists has brought about a more detailed taxonomy of natural forms, if for the price of higher specialization and decreased general usage (see Lee, 1979, p. 180; Widlok, 1999, p. 87). With regard to landscape and place names this contribution has shown that hunter-gatherers like the $\neq$ Akhoe Hai//om do not necessarily have a more elaborate or more 
coherent system of reference than, say, their Bantu- or Khoisan-speaking neighbours. In certain ways it may even be characterized by its relative lack of orthodoxy and by "mixing" frames of references with regard to the axes of the body and the landscape. They also do not have a clearly personalized ideology of the environment in terms of "mother earth" or a totemic system of places. To be sure, landscape vocabulary is ubiquitous in $\neq$ Akhoe Hai//om discourse, since it plays a critical role in directionals and other forms of "topographical gossip". However, the most characteristic feature is that their landscape-cum-group terminology merges settlements with landscapes. It thereby facilitates an easy shift between landscape (or any large-scale area) names and place names as well as more fundamentally between what in scientific discourse are distinguished as names and terms.

These results, based on systematic elicitation tasks and more general participant observation, have been recently confirmed by cognitive research involving the same group of $\neq$ Akhoe Hai//om speakers (Haun et al., forthcoming). This research adds to the body of literature that documents cases in which non-relative (or non-speaker-centred) frames of reference are used in spatial language and orientation. In contrast to the earlier bias, cultivated in large parts of European philosophy, that considered the body-centred frame of reference to be natural, it may now seem that the "environmental" frame (such as that of the $\neq$ Akhoe Hai//om) is somehow closer to a human (or primate) "default" strategy. However, both assumptions take the division between body and environment, speaker and the landscape - and ultimately that between nature and culture - for granted. The data presented here suggests that neither the bodily-centred nor the environment-centred perception should be considered to be "naturally given". We should also not take it for granted that one could usefully compare the ways in which cultures map their ontologies, be they body-centred or environmental, with reference to the physiographic features as identified by sciences that are premised on these distinctions. It is not coincidental therefore that branches of Western philosophy that are critical of these distinctions and of the dominant natural science paradigm would frequently refer to the hunter-gatherer ethnography to substantiate their critique (see for instance Ingold, 2000). They maintain that the difference may be more fundamental and argue that in the light of evidence from huntergatherers the notion of a generic grid of landscape terms is the result not of a universal condition but of a rather specific culture in which humans are alienated from their engagement with the rest of the world.

We need not share this radical critique of science but I suggest that there is enough evidence to question the assumption that landscape and place terminology is primarily a matter of reference to nature from a position of cultural detachment. We may, more or less successfully, distil a system of generic landscape terms from language relating to landscape but we may thereby miss much more fundamental differences in the way in which humans relate to the landscape. I suggest that future research into aspects of language involving landscape and place should consider the possibility that in topographical talk there are also what, in kinship studies, are called terms of address, not only terms of reference. In the particular case discussed here the landscape is not addressed in a mystical fashion of personalized or divinized natural features that is found in some parts of the world. From an emic perspective it seems that the landscape in a sense is addressing the speakers who dwell in it and that their place names are responses to events in - and features of - the landscape. Research into landscape terminology has been largely focused on taxonomies, on the "vertical" delimitation of landscapes in particular by contrasting "larger" landscapes with 
"smaller" places, and systematizing how they relate to one another. ${ }^{11}$ The material presented here suggests another dimension, namely that of the "horizontal" extension of landscape terms not only across different types of landscapes but across the boundaries of an externally defined semantic domain of landscape itself that merges into the neighbouring domains of settlement, migration patterns, resource use and group formation.

From the evidence presented here we may suggest that $\neq$ Akhoe Hai//om speakers do not readily make the distinctions that are entrenched in Western science but that they consider both the body and the landscape as equally "given" and as equally "constructed" through naming and other means of language use, in other words as being both natural and cultural. The landscape, and the body for that matter, are considered "given" in the sense that they form not just the environment but parts of the universe that is the origin rather than merely the "surrounding" or "frame" of human existence. They are considered to be constructed insofar as the use of language allows humans to understand their engagement with what is given around them but without being external to these "givens". The human senses participate in the "environment" and have evolved with the general evolution of the body and the landscape. The human beings who move in space and who talk about landscape are still part of the land by origin as well as through their continuing reliance upon it. There are indications that the insistence to separate out "the landscape" from human practices, including the naming of places as well as the moving through space, is not found in $\neq$ Akhoe Hai//om cultural practice and that this may not be the only case. Similarities have not only been observed with regard to other hunter-gatherer groups (see Ingold, 2000) but similar views have also been aired by phenomenological anthropology about the conditio humana more generally (see Løgstrup, 1994). Both suggest that we are all "Bushmen", in the sense of being part in people-cum-land units, but that we differ to the degree in which we maintain an unrealistic image of ourselves as separated from a landscape or an environment that merely surrounds us.

\section{Acknowledgements}

I am grateful to all $\neq$ Akhoe Hai//om who included me in their "topographical gossip" over the years, and for their patience. This article is dedicated to the late Lazarus "Dãdãb" Kalutenda who spent many days travelling through the bush with us. I also thank Niclas Burenhult, Christian Rapold and three anonymous reviewers who have commented on earlier drafts of this paper. Research for this paper was conducted under the auspices of the Language and Cognition Group, headed by Stephen Levinson, at the Max Planck Institute for Psycholinguistics in Nijmegen with funds from the Volkswagen Foundation.

\section{References}

Atran, S., 1990. Cognitive foundations of natural history. In: Towards an Anthropology of Science. Cambridge University Press, Cambridge.

Barnard, A., 1988. Cultural identity, ethnicity and marginalization among the Bushmen of Southern Africa. In: Vossen, R. (Ed.), New Perspectives on Khoisan. Buske, Hamburg, pp. 9-27.

\footnotetext{
11 There is a parallel here to the study of folk biology which has been preoccupied with "vertical" taxonomies and how they map onto the common sensical life forms (Atran, 1990). In this sense "landscapes" are often considered to be the life forms of the ground, as it were.
} 
Barnard, A., 1992. Hunters and herders of Southern Africa. In: A Comparative Ethnography of the Khoisan Peoples. Cambridge University Press, Cambridge.

Barnard, A., Widlok, T., 1996. Nharo and Hai//om settlement patterns in comparative perspective. In: Kent, S. (Ed.), Cultural Diversity Among Twentieth-Century Foragers: An African Perspective. Cambridge University Press, Cambridge, pp. 87-101.

Berry, H., Rochèr, S., Paxton, M., Cooper, T., 1996. Bedeutung und Ursprung der Ortsnamen im Etoscha Nationalpark. Namibia, Windhoek.

den Besten, H. 2003. The Pidgin (and English) roots of Afrikaans Booi and Boesman. In: Botha, W. (Ed.), 'n Man wat beur. Huldigingsbundel vir Dirk van Schalkwijk. Buro van die WAT, Stellenbosch, pp. 183-194.

Bleek, D., 1956. A Bushman Dictionary. American Oriental Society, New Haven.

Gordon, R., 1992. The Bushman Myth. In: The Making of a Namibian Underclass. Westview Press, Boulder.

Haacke, W., 1977. The so-called "Personal Pronoun" in Nama. In: Traill, A. (Ed.), Khoisan Linguistic Studies 3. Witwatersrand University Press, Johannesburg, pp. 43-62.

Haacke, W., Eiseb, E., 2002. A Khoekhoegowab Dictionary with an English- Khoekhoegowab Index. Gamsberg Macmillan, Windhoek.

Hanks, W., 1996. Language and Communicative Practice. Westview Press, Boulder.

Haun, D., Rapold, C., Janzen, G., Levinson, S.C., forthcoming. Right might be wrong where West is right: Spatial language and cognition across two cultures.

Hertz, R., 1960. La prééminence de la main droite: Etude sur la polarité religieuse. In: Needham, R., Needham, C. (Eds.), "Death" and "The Right Hand". Cohen and West, London, pp. 89-113.

Hutchins, E., 1995. Cognition in the Wild. MIT Press, Cambridge.

Ingold, T., 2000. The perception of the environment. In: Essays in Livelihood, Dwelling and Skill. Routledge, London.

Ingold, T., 2005. Time, memory and property. In: Widlok, T., Tadesse, W. (Eds.), Property and Equality, In: Ritualisation, Sharing, Egalitarianism, vol. 1. Berghahn, New York, pp. 165-174.

Kathage, B., 2004. Konzeptualisierung von Landschaft im Mbukushu. Köppe, Köln.

Kopytoff, I., 1989. The African Frontier. Indiana University Press, Bloomington.

Köhler, O., 1989. Die Welt der Kxoé-Buschleute im südlichen Afrika: eine Selbstdarstellung in ihrer eigenen Sprache. Reimer, Berlin.

Lee, R., 1979. The !Kung San: Men, Women, and Work in a Foraging Society. Cambridge University Press, Cambridge.

Levinson, S.C., 1996. The Role of Language in Everyday Human Navigation. Max Planck Institute for Psycholinguistics, Nijmegen.

Levinson, S.C., 2003. Space in Language and Cognition: Explorations in Cognitive Diversity. Cambridge University Press, Cambridge.

Løgstrup, K., 1991. Weite und Prägnanz. In: Sprachphilosophische Betrachtungen. Mohr, Tübingen.

Løgstrup, K., 1994. Ursprung und Umgebung. In: Betrachtungen über Geschichte und Natur. Mohr, Tübingen.

Needham, R., 1973. Left and Right. University of Chicago Press, Chicago.

Neumann, S., Widlok, T., 1996. Rethinking some universals of spatial language using controlled comparison. In: Dirven, R., Pütz, M. (Eds.), The Construal of Space in Language and Thought. De Gruyter, Berlin, pp. 345369 .

Nienaber, G., Raper, P., 1977. Toponymica Hottentotica A. HSRC, Pretoria.

Nienaber, G., Raper, P., 1981. Toponymica Hottentotica B. HSRC, Pretoria.

Schatz, I., 1993. Unter Buschleuten auf der Farm Otjiguinas in Namibia, Tsumeb.

Schladt, M. (Ed.), 1998. Language, Identity, and Conceptualization Among the Khoisan. Köppe, Köln.

Widlok, T., 1996. Topographical Gossip and the Indexicality of Hai//om Environmental Knowledge. Max Planck Institute for Psycholinguistics, Nijmegen.

Widlok, T., 1997. Orientation in the Wild: the Shared Cognition of Hai//om Bushpeople. Journal of the Royal Anthropological Institute 3, 317-332.

Widlok, T., 1998. Cognitive foundations of Khoisan common sense. In: Schladt, M. (Ed.), Language, Identity, and Conceptualization Among the Khoisan. Köppe, Köln.

Widlok, T., 1999. Living on Mangetti. In: 'Bushman’ Autonomy and Namibian Independence. Oxford University Press, Oxford.

Widlok, T., 2003. The needy, the greedy and the state: dividing Hai//om land in the Oshikoto region. In: Hohmann, T. (Ed.), San and the State. Contesting Land, Development, Identity and Representation. Köppe, Köln, pp. 87-119. 
Widlok, T., 2007. Conducting cognitive tasks - and interpreting the results. The case of spatial inference tasks. In: Wassmann, J., Stockhaus, K. (Eds.), Person, Space and Memory in the Contemporary Pacific. Experiencing of New Worlds. Berghahn, Oxford, pp. 258-280.

Widlok, T., forthcoming. Where settlements and the landscape merge: towards an integrated approach to the spatial dimension of social relations. In: Bollig, M., Grundkowski, N. (Eds.), Landscape in Interdisciplinary Perspective.

Williams, F.-N., 1991. Precolonial communities of Southwestern Africa. In: A History of Owambo Kingdoms 1600-1920. National Archives of Namibia, Windhoek.

Winter, J., 1981. Die Khoisan-Familie. In: Heine, B., Schadeberg, T., Wolf, E. (Eds.), Die Sprachen Afrikas. Buske, Hamburg, pp. 328-374. 